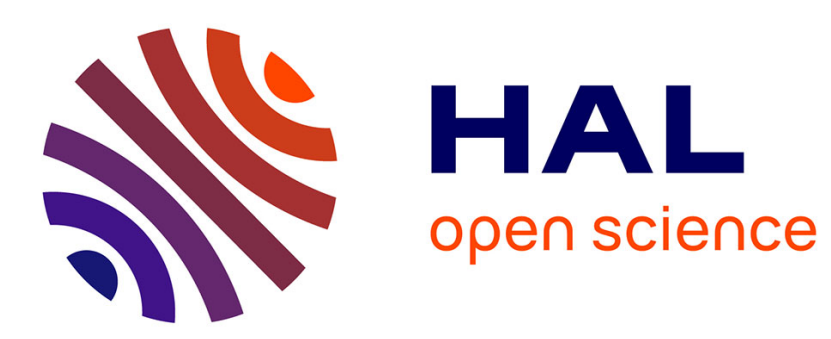

\title{
French teachers' general attitude toward inclusion: the indirect effect of teacher efficacy
}

Caroline Desombre, Mathilde Lamotte, Mickaël Jury

\section{To cite this version:}

Caroline Desombre, Mathilde Lamotte, Mickaël Jury. French teachers' general attitude toward inclusion: the indirect effect of teacher efficacy. Educational Psychology, 2019, 39 (1), pp.38-50. 10.1080/01443410.2018.1472219 . hal-01859627

\section{HAL Id: hal-01859627 \\ https://hal.science/hal-01859627}

Submitted on 5 Oct 2021

HAL is a multi-disciplinary open access archive for the deposit and dissemination of scientific research documents, whether they are published or not. The documents may come from teaching and research institutions in France or abroad, or from public or private research centers.
L'archive ouverte pluridisciplinaire $\mathbf{H A L}$, est destinée au dépôt et à la diffusion de documents scientifiques de niveau recherche, publiés ou non, émanant des établissements d'enseignement et de recherche français ou étrangers, des laboratoires publics ou privés. 


\section{French Teachers' General Attitude Toward Inclusion: The Indirect Effect of Teacher Efficacy}

$$
\text { Caroline Desombre }{ }^{1} \text {, Mathilde Lamotte }{ }^{2} \& \text { Mickaël Jury }{ }^{1}
$$

1 ESPE Lille Nord de France and Univ Lille-Nord de France, Université de Lille 3, PSITEC - EA 4072 2 Research Unit INSIDE, University of Luxembourg, Campus Belval, Esch-sur-Alzette, Luxembourg The authors declare that there are no potential conflicts of interest with respect to the research, authorship, and/or publication of this article.

This paper has been accepted for publication in Educational Psychology. This version is a post-print. This research was supported by the Ecole Supérieur du Professorat et de l'Education Lille Nord de France.

We wish to thank Jennifer Vercaigne and Lise Meurice for their help in data collection. Corresponding author: Caroline Desombre, ESPE Lille Nord de France, 365 Bis Rue Jules Guesde, 59650 Villeneuve-d'Ascq, France. Phone number: +33 (0)3 207986 00. Email:

caroline.desombre@espe-Inf.fr. 


\begin{abstract}
The inclusion of children with special educational needs is a major challenge. Amongst the factors linked to a successful inclusive education policy, teachers' attitude toward inclusion is particularly important. The present paper seeks to understand why general teachers exhibit less favorable attitude toward inclusion than special education teachers. We argue that general teachers' low sense of efficacy can act as a mediator. To investigate this hypothesis, general and special education teachers were asked to report their attitude and efficacy. Results confirm that general teachers have less positive attitude toward inclusion than special education teachers. In addition, a mediational analysis confirmed that this discrepancy is partly sustained by general teachers' lower sense of efficacy. Limits as well as future perspective are discussed.
\end{abstract}

Keywords: Teacher efficacy, mainstream education, special educational needs, attitude toward inclusion, general teachers. 


\section{French Teachers' General Attitude Toward Inclusion: The Indirect Effect of Teacher Efficacy}

To promote diversity among schoolchildren, most European countries have legislated for the development of inclusive practices in their education system (Ferguson, 2008; Meijer, 2010; Thomazet, 2008). These political measures aim to counteract the social exclusion of some children due to their ethnicity, religiosity, social status, gender, abilities, and notably those with Special Educational Needs (SEN, i.e., students who face learning problems or disabilities that make learning more difficult for them than for same-aged children without learning problems or disabilities). However, implementing such policy remains difficult (Ferguson, 2008) and teachers' attitude toward inclusion could notably act as a barrier (De Boer, Spijl, \& Minnaert, 2011). The purpose of the present paper is to specifically examine why general teachers (i.e., those who teach in mainstream education), in comparison with special education teachers (i.e., teachers who benefit from a specific training and teach students with SEN in mainstream or special education), are less favorable toward inclusion. Based on previous research, we notably argue that general teachers' low sense of efficacy would prevent them from endorsing positive attitude toward inclusion. Such a hypothesis will be examined in a French context in which the inclusion of students with SEN is still particularly disputed (see Ebersold, Plaisance, \& Zander, 2016; Plaisance, 2012).

\section{Teachers' Attitude Toward Inclusion}

The World Conference on Special Needs Education in Salamanca defined the basis for inclusion (Vislie, 2003). According to the Salamanca Declaration (United Nations Educational, Scientific and Cultural Organisation, 1994, p. ix), "regular schools with this inclusive orientation are the most effective means of combating discriminatory attitudes, creating welcoming communities, building an inclusive society and achieving education for all; moreover, they provide an effective education to the majority of children and improve the efficiency and ultimately the cost-effectiveness of the entire education". In other words, inclusion seems to promote positive attitude toward students with SEN and increase students' achievement (for a meta-analysis, see Ruijs \& Peetsma, 2009).

In inclusive settings, students with SEN receive their entire academic curriculum in mainstream education, enrolled with students of their age groups. In such a system, schoolteachers are asked to meet the needs of all learners, that is, they should adapt their practices in order to help every student, including those with SEN, to reach his/her full potential. Therefore, the success of inclusion notably depends on teachers and their attitude toward inclusion (Elliott, 2008; Leatherman \& Niemeyer, 2005). Nonetheless, even if teachers' attitude toward inclusion was positive (Scruggs \& Mastropieri, 1996), it does not mean that teachers are willing to accept "full inclusion" (Avramidis \& Norwich, 2002), much less agree to include a student with SEN within their own classroom (deBettencourt, 1999; Ward, Center \& Bochner, 1994).

A range of variables has been found to influence attitude toward inclusion (for reviews, see Avramidis \& Norwich, 2002; De Boer et al., 2011). Thus, teachers' attitude seems to depend on the extent to which instructional practices should be modified to accommodate students' curricula (Center \& Ward, 1987) as well as the nature and severity of special educational needs. More precisely, teachers expect that students with emotional and behavioral difficulties as well as those with profound 
and multiple learning difficulties are the most difficult to include (Avramidis, Bayliss, \& Burden, 2000; Avramidis \& Norwich, 2002). In addition, attitude also varies as a function of educational policy in the country (Savolainen, Engelbrecht, Nel, \& Malinen, 2012; Takala, Haussttätter, Ahl, \& Head, 2012), school resources or support for inclusive practices, including from the board (Avramidis \& Norwich, 2002; Urton, Wilbert, \& Hennemann, 2014). Finally, teachers' attitude also appears to depend on teachers' characteristics. For examples, women and younger teachers - in terms of age and experiences - have more favorable attitude toward inclusion (Alghazo \& Naagar Gad, 2004, Avramidis et al., 2000).

Concerning teachers' characteristics, literature has also identified a persistent difference in teachers' attitude based on their position. More precisely, and as evoked above, research has demonstrated that general teachers usually have less favorable attitude toward inclusion than their special education counterparts (McHatton \& Parker, 2013; Minke, Bear, Deemer, \& Griffin, 1996; Shippen, Crites, Houchins, Ramsey, \& Simon, 2005; Tournaki \& Samuels, 2016). If several works of research have examined different ways to reduce this difference (see for an example Tournaki \& Samuels, 2016), empirical research that specifically examines a psychological mechanism sustaining this difference has yet to be carried out. In the present paper, we propose to test teacher efficacy as a potential mediator of attitude toward inclusion.

\section{Teacher Efficacy}

Self-efficacy is defined as "beliefs in one's capabilities to organize and execute the courses of action required to produce given attainments" (Bandura, 1997, p. 3). According to Bandura (1997), self-efficacy determines the organization and regulation of behavior. It leads people to choose activities that will enhance the acquisition of knowledge and skills. In education, teacher efficacy refers to 'teachers' belief or conviction that they can influence how well students learn, even those who may be considered difficult or unmotivated" (Guskey \& Passaro, 1994, p. 628). Several researchers point out the role of self-efficacy beliefs in engagement and choice of goals. In a school context, teachers with high efficacy are more engaged and persist longer in assisting students with learning difficulties (Woolfolk Hoy, Hoy, \& Davis, 2009). Efficacy also influences teaching behaviors and the use of didactic innovations in classrooms (Holzberger, Philipp, \& Kunter, 2013; Schiefele \& Schaffner, 2015, for a review see Zee \& Koomen, 2016).

Bandura (1997) argued that one's sense of self-efficacy depends on four sources: mastery experiences, vicarious experiences, social persuasion, and somatic and emotional states (see also Fernandez, Ramos, Silva, Nina, \& Pontes, 2016; Morris, Uscher, \& Chen, 2016). Mastery experiences are defined as a sense of satisfaction with one's past successful teaching experiences. Vicarious experiences are represented by models of success or failure observed in the actions of other teachers. Social persuasion refers to self-efficacy judgments based on verbal stimulation of other important people such as colleagues, supervisors and managers, as well as affective and emotional states represent the control of the activation level (i.e., fatigue, stress, anxiety, tension, mood), which in turn can directly affect judgments about teaching ability (Fernandez et al., 2016).

In contrast, research has also identified that certain teacher-related parameters are usually associated with teacher efficacy. Thus, for examples, teaching experience and grade taught have 
been identified as antecedents of teacher efficacy (see Klassen \& Chiu, 2010). As for teachers' attitude toward inclusion, research has also illustrated that teachers' position play a role in their sense of efficacy. Indeed, Buell and her colleagues (Buell, Hallam, Gamel-Mccormic, \& Scheer, 1999) have demonstrated that special education teachers have a higher sense of efficacy than general teachers. In the same way, Leyser, Zeiger, and Romi (2011) illustrated that pre-service teachers majoring in special education already have a higher sense of efficacy than those majoring in general education.

As a result, and due to the consistent positive link observed between teacher efficacy and attitude toward inclusion (Savolainen et al., 2012; Soodak, Podell, \& Lehmann, 1998; Urton et al., 2014; Weisel \& Dror, 2006; Yada \& Savolainen, 2017), it seems reasonable to expect that general teachers' less favorable attitude toward inclusion in comparison with special education teachers (McHatton \& Parker, 2013; Minke et al., 1996; Shippen et al., 2005; Tournaki \& Samuels, 2016) would be explained by the difference in efficacy (Buell et al., 1999; Leyser et al., 2011). A correlational study was conducted in France in order to examine this hypothesis.

\section{Inclusion in France}

In France, the inclusion of students with SEN has been mandatory since 2005 (LOI n²005102) but only fully went into effect in 2013 (LOI n²013-595). As a result, the current trends are towards more inclusive education (Desombre, 2009) and the number of students with SEN included in mainstream education have consistently increased over the last years (e.g., this number grew by $7.5 \%$ last year to reach a total of 300,815 included students, French Ministry of Education, 2017). However, as in others countries, inclusion faces barriers and general teachers continue to express concerns regarding the inclusion of students with SEN. Lack of training is one of the most frequently invoked reasons by general teachers to justify their attitude (Rattaz et al., 2013). Indeed, it should be acknowledged that until recently in France, training on instructing students with SEN was not a mandatory part of the 2-year teaching curriculum. Conversely, to become a special education teacher, general teachers had to pursue a 400-hour training program exclusively dedicated to inclusive behaviors (e.g., designing and using instructional and curricular adaptations). Since training is particularly linked to teacher efficacy (Buell et al., 1999; Leyser et al., 2011), we believe that such a discrepancy between general and special education teachers is particularly likely to explain French general teachers' attitude toward inclusion. Therefore, identifying a mechanism sustaining the obstacles to inclusion could be particularly helpful in furthering develop tools to overcome these barriers in France and throughout the world.

\section{Method}

\section{Participants.}

Five hundred and fifty-four teachers from three different areas of France participated voluntarily in this study. The sample included 113 men and 441 women with a mean age of 41.12 years $(S D=9.38)$. Four hundred and one participants were general teachers and 153 participants were special education teachers. Three hundred and one participants taught in elementary schools, and 253 taught post-elementary grades (middle school, high school and university). Overall, participants possessed a mean experience of 16.21 years $(S D=9.71)$ in their job. 
General teachers were mostly women (i.e., 80.04\%) who taught at elementary schools (i.e., $58.60 \%$ ). Special education teachers were also mostly women (i.e., $78.43 \%$ ) who taught primarily at post-elementary levels (i.e., 56.86\%). General and special education teachers did not differ in terms of age or teaching experience (all ts $<1$ ).

\section{Material.}

Teacher efficacy. The 15-item questionnaire developed by Gibson and Dembo (1984; validated in French by Dussault, Villeneuve, \& Deaudelin, 2001) was submitted to participants in order to assess their efficacy as teachers. Participants also indicated the extent to which they agreed with the items on a 5-point scale from 1 , "Totally disagree", to 5 , "Totally agree". Responses were projected across a measure of general efficacy and a measure of personal efficacy. Since the latter directly measured teacher's beliefs regarding his or her practices (e.g., "When a student faces difficulties in a task, I am usually able to adapt this task to his level of competence", "When students' grades improve, it is usually because I have found more efficient teaching practices"), this section of the scale was used as the measure of teacher efficacy. If ten items usually composed this measure, it should be noted that for a reliability reason, nine items were finally retained here (i.e., item \#15 was excluded) to compute the mean score $(\square=.74, M=3.48, S D=0.52)$. However, replication of the analyses with the 10 -item score did not change the results.

Attitude toward inclusion. Participants completed a tool devised by Mahat (2008). This 18item scale assesses teachers' attitude toward inclusion (e.g., " I believe that an inclusive school is one that permits academic progression of all students regardless of their ability.", "I get irritated when I am unable to understand students with a disability.") on a 5-point scale from 1, "Totally disagree", to 5 , "Totally agree". Reliability analysis was satisfactory $(\square=.88)$ and a mean score was computed $(M=3.90, S D=0.61)$. Means, standard deviations and correlations between variables are displayed in Table 1. 
Table 1

Zero-order correlations between variables

\begin{tabular}{lrrrrrrrr}
\hline & $M$ & $S D$ & 1 & 2 & 3 & 4 & 5 & 6 \\
\hline 1. Teacher Efficacy & 3.48 & 0.52 & - & & & & & \\
2. Attitude toward & 3.90 & 0.61 & $.43^{* * *}$ & & & & & \\
inclusion & & & $-25^{* * *}$ & $.34^{* * *}$ & & & & \\
3. Position & - & - & .06 & .03 & $.14^{*}$ & & & \\
4. Level of teaching & $16 . \overline{21}$ & $9 . \overline{71}$ & $.10^{*}$ & -.01 & .01 & $.08^{\star}$ & & \\
5. Experience & 41.12 & 9.38 & $.10^{*}$ & .01 & .03 & $.08^{*}$ & $.90^{* * *}$ & $-\bar{C}^{*}$ \\
6. Age & - & - & -.02 & .04 & -.02 & $-.26^{* * *}$ & $-.09^{*}$ & $-.10^{*}$ \\
7. Gender & - & &
\end{tabular}

Note: Position is coded -0.5 for general teacher and +0.5 for special education teacher. Level of teaching is coded -0.5 for elementary school and +0.5 for above elementary. Gender is coded -0.5 for male and +0.5 for female. ${ }^{t} p<.10,{ }^{*} p<.05,{ }^{* * *} p<.001$

\section{Procedure.}

Participants were invited by email to complete an online version of the questionnaire during the spring semester of the 2016-2017 school year. Participants were contacted through different national teachers' associations, the center for teacher training (i.e., "Ecole Supérieure du Professorat et de l'Education") as well as various education authorities (e.g., at a local and regional level). Participants came from three different areas of France known to be representative of French diversity in terms of population density, economic activities and number of students with SEN. No information was collected regarding participants' geographical origin (e.g., neither school, nor city of origin).

The email sent out informed participants about the study's purpose as well as the way in which it would be conducted. Afterward, participants were invited to give their consent. At this time, they were informed that their participation was voluntary, that they could quit the study without consequences and that they would not receive any financial compensation for their participation. Once consent was given, participants were asked to fill in the measures of teacher's efficacy and attitude toward inclusion. At the end of the questionnaire, they completed demographic information and received more detailed information regarding the purpose of the study.

\section{Statistical analysis.}

The purpose of the present paper was to test the hypothesis that general teachers were less favorable toward inclusion than special education teachers because they experienced a lower sense of efficacy than special education teachers. Therefore, analyses of mediation were conducted following the guidelines provided by Preacher and Hayes (2004; 2008). More precisely, the confidence interval of the indirect effect (i.e., the mediating effect of teacher efficacy) was estimated following a bootstrapping method with a 5,000 bootstrap resamples. Such a method is particularly recommended when the presence of an indirect effect is tested (Hayes, 2009). In the statistical model, teacher's position was contrast coded: -0.5 for general teachers and +0.5 for special education teachers (see Davis, 2010).

In addition, since age, gender and teaching experiences are known to influence attitude toward inclusion in literature, preliminary analyses were conducted while controlling for the influence of these parameters. In said analyses, attitude toward inclusion and teacher efficacy were regressed on a model including teacher's position, age, gender (coded -0.5 for men and +0.5 for women), teaching 
experiences and teaching level (coded -0.5 for elementary schools and +0.5 for above elementary schools).

Finally, it is worth noting that in this research, no manipulations nor data exclusions were used. All variables analyzed are reported, and all data were collected before any analyses were conducted. All material and data can be accessed at: https://osf.io/fe4t7/.

\section{Results}

Preliminary analysis. As indicated above, preliminary analyses on attitude toward inclusion and teacher efficacy were conducted.

Regarding attitude, the overall model was significant, $F(5,532)=14.99, p<.001, R^{2}=.12$, and the analysis revealed that teacher's position was the only significant predictor $(\beta=.34, S E=.04$, $p<.001,95 \%$ Cls $[.26, .42])$. Indeed, neither age $(\beta=.08, S E=.09,95 \%$ Cls $[-.09, .26])$, gender $(\beta=.04, S E=.04,95 \%$ Cls $[-.04, .11])$, teaching experience $(\beta=-.09, S E=.09,95 \%$ Cls $[-.27, .08])$, nor teaching level $(\beta=-.00, S E=.04,95 \%$ Cls $[-.08, .08])$ was related to attitude (all $p s>.32$ ).

Regarding teacher efficacy, the overall model was also significant, $F(5,532)=8.30, p<.001$, $R^{2}=.07$, and the analysis also indicated that teacher's position was the only significant predictor $(\beta=.24, S E=.04, p<.001,95 \%$ Cls $[.16, .32])$. As previously, neither age $(\beta=.03, S E=.09,95 \%$ Cls $[-.15, .21])$, gender $(\beta=-.00, S E=.04,95 \%$ Cls $[-.08, .08])$, teaching experience $(\beta=.07$, $S E=.09,95 \%$ Cls $[-.11, .25])$, nor teaching level $(\beta=.02, S E=.04, p=.59,95 \%$ Cls $[-.06, .10])$ was related to teacher efficacy (all $p s>.45$ ). As a consequence, these parameters were not retained in the final models.

Main analysis. Firstly, results indicated that teachers' position predicted attitude toward inclusion, $\beta=.34, S E=.04, t(552)=8.55, p<.001,95 \%$ Cls [.26, .42], $R^{2}=.12$; General teachers $(M=3.77, S E=.03)$ expressed less favorable attitude toward inclusion than special education teachers $(M=4.24, S E=.05)$. Secondly, as expected, teachers' position predicted teacher efficacy, $\beta=.25, S E=.04, t(552)=6.05, p<.001,95 \%$ Cls $[.16, .33], R^{2}=.06$; General teachers $(M=3.40$, $S E=.03)$ expressed less confidence toward their teaching abilities than special education teachers $(M=3.69, S E=.04)$. Finally, teacher efficacy was positively related to attitude toward inclusion, $\beta=.43, S E=.04, t(552)=11.06, p<.001,95 \%$ Cls $[.35, .50], R^{2}=.18$; The more confident participants were about their teaching abilities, the more favorable they were to inclusion.

Results of the mediation analysis confirmed the indirect effect of teacher efficacy on the relationship between teachers' position and attitude toward inclusion, $\beta=.09,95 \% \mathrm{Cls}[.05 ; .13]$. In other words, special education teachers expressed more favorable attitude toward inclusion compared to general teachers, partly due to their higher perceived efficacy. Nonetheless, it should be noted that the direct effect of teachers' position on attitude remained significant, $\beta=.25, S E=.04, t(551)=6.56$, $p<.001,95 \%$ Cls $[.17, .32]$. The results of the mediation analysis are displayed in Figure 1.

Two additional pieces of information should be noted. First, the instrument used here distinguishes between the three components of attitude (i.e., cognition, emotion and behavior). However, since no hypotheses were formulated on these distinct dimensions, analyses were conducted on the general attitudinal score. For the sake of transparency, it is worth noting that replicating the analysis on each component separately showed the same results as those for the 
general attitudinal score. Secondly, due to unequal sample sizes, additional analyses using the "wec" package for $\mathrm{R}$ (te Grotenhuis et al., 2017) and Welch $t$-tests (see Delacre, Lakens \& Leys, 2017) were conducted in order to avoid misinterpreting the findings. Results were unchanged and confirmed that teacher's position is associated with attitude toward inclusion $(p<.001)$ and teacher efficacy

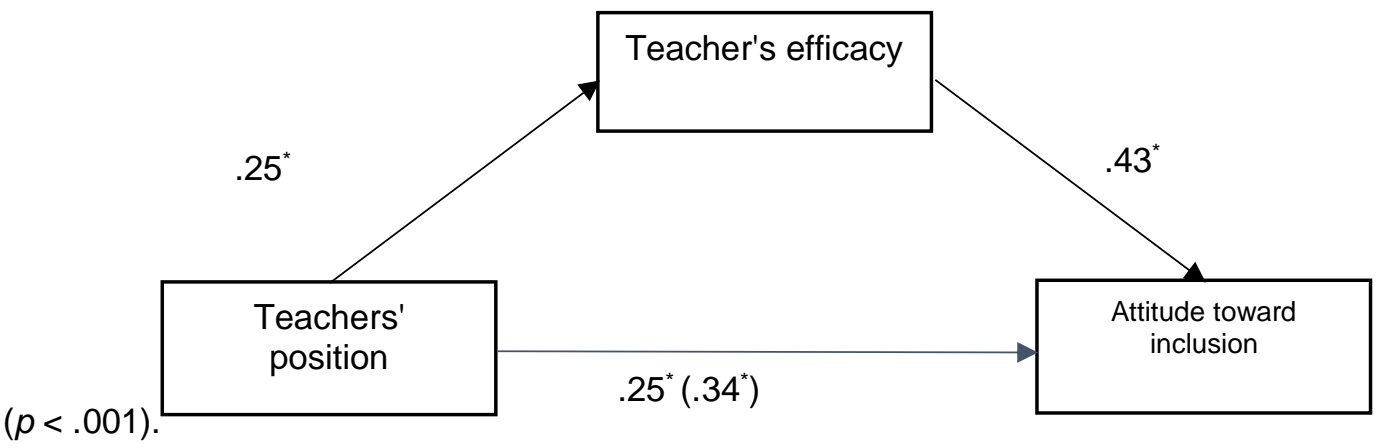

Note. Position is coded -0.5 for regular teachers and +0.5 for special education teachers. ${ }^{*} p<.001$

Figure 1. Mediation analysis of teachers' attitude toward inclusion through teacher's efficacy (Position is coded -0.5 for general teachers and +0.5 for special education teachers. ${ }^{*} p<.001$ ).

\section{Discussion}

The inclusion of students with SEN in mainstream education is a challenge in current education (Ferguson, 2008). Among the identified barriers, general teachers' attitude toward inclusion has received a great deal of attention in literature (Avramidis \& Norwich, 2002; De Boer et al., 2011). The goal of the present study was to test, in France, whether the usual difference observed between general and special education teachers in terms of attitude (toward inclusion) could be explained by their respective sense of efficacy.

Indeed, in view of previous results (Buell et al., 1999; Leyser et al., 2011; McHatton \& Parker, 2013; Minke et al., 1996; Savolainen et al., 2012; Shippen et al., 2005; Soodak et al., 1998; Tournaki \& Samuels, 2016; Urton et al., 2014; Weisel \& Dror, 2006; Yada \& Savolainen, 2017), we argue that general teachers would exhibit less favorable attitude toward inclusion than special education teachers because of their lower sense of efficacy. To investigate this hypothesis, general and special education teachers reported their attitude toward inclusion and their sense of efficacy. Our results confirmed our prediction. In other words, the present research supports the idea that efficacy is a key mechanism for explaining general teachers' less favorable attitude toward inclusion (in comparison with special education teachers). These results emphasize the importance of considering general teachers' efficacy in improving students with SEN inclusion since research showed the positive links that attitude and efficacy have respectively with behavioral intentions to include students with SEN and effective interventions toward these students (Allinder, 1994; Brownell \& Pajares, 1999; MacFarlane \& Woolfson, 2013; Soodak et al., 1998; Wertheim \& Leyser, 2002; Wilson, Woolfson, Durkin, \& Elliott, 2016).

Amongst the four different sources of self-efficacy (see Fernandez et al., 2016; Morris et al., 2016), Bandura (1997) argued that mastery experience is the most powerful. Therefore, since inclusion is not yet generalized (at least in France), general teachers' lower confidence in their 
teaching practices (in comparison with special education teachers) may result from their being granted fewer experiences and opportunities to assess and improve their teaching practices with students with SEN. In addition, and as mentioned above, special education teachers in this country receive annual part-time training in addition to their initial curriculum. This training is designed to give them more resources to deal with students with SEN and may improve both their general and particular (i.e., for inclusive practices) sense of efficacy (Chao, Sze, Chow, Forlin, \& Ho, 2017; Forlin, Loreman, \& Sharma, 2014; Lancaster \& Bain, 2007; Leyser et al., 2011). Therefore, the differences found here may either translate a difference in training or a difference in terms of experience, or both. To solve this issue, further research could first replicate the present findings while statistically controlling for teachers' previous experiences with students with SEN. Then, to examine the influence of the special education training program, a longitudinal study could also compare the evolution of general efficacy (throughout the program) of teachers who undergo the training program with that of teachers who do not benefit from the program but who have a similar profile in terms of age, teaching experience, level of teaching and experience with students with SEN.

It bears mentioning some limitations of this work. First, in the present study, all measures were invoked variables. Therefore, causality cannot be established and results regarding the mediational analysis should be read cautiously. Though it does not make sense that attitude toward inclusion should influence sense of efficacy, such a possibility cannot be ruled out by our data. Second, research showed that attitude could vary according to the kind of attitude (i.e., general or specific, see Ajzen \& Fishbein, 2005). For example, as evoked above, a discrepancy exists between teachers' general attitude towards the concept of inclusion (Scruggs \& Mastropieri, 1996, see also Abbott, 2006) and their specific willingness to include a student with SEN in their classroom (deBettencourt, 1999, see also Florian, 1998). In the present study, the used instrument was designed to measure general attitude toward inclusion (Mahat, 2008). Future research could examine if the indirect effect obtained here would vary depending on attitude type. Thirdly, it should also be acknowledged that even if efficacy acts as a mediator, the direct effect between teacher's position and attitude toward inclusion remains significant, leaving space for other potential mediators. Future studies should investigate these issues. Finally, it should be noted that the participants in the present study may not perfectly represent other French teachers. Indeed, since they deliberately chose to participate in a study about inclusion, it cannot be ruled out that these teachers already had a precise idea about inclusion (either positive or negative) that they would like to share.

Notwithstanding these limitations and research perspectives, the results of this study illustrate that to sustain an inclusive school system, general teachers must experience more confidence in their teaching practices. Therefore, in line with recent educational reforms in France, increasing the amounts of theoretical and practical knowledge received by pre-service teachers appears to be a relevant way to hone teachers' ability to teach in inclusive settings. Such curriculum modifications are undoubtedly steps forward to a more inclusive education despite the tangible effects still needing to be tested. 


\section{References}

Abbott, L. (2006). Northern Ireland head teachers' perceptions of inclusion. International Journal of Inclusive Education, 10(6), 627-643. doi: 10.1177/17444629506067618

Ajzen, I. \& Fishbein, M. (2005). The influence of attitudes on behavior. In D. Albarracín, B. T. Johnson, M. P. Zanna (Eds). Handbook of attitudes and attitude change (pp. 173-221). Mahwah, NJ: Erlbaum.

Alghazo, E. M., \& Nagar Gaad, E. E. (2004). General education teachers in the United Arab Emirates and their acceptance of the inclusion of students with disabilities. British Journal of Special Education, 31(2), 94-99. doi: 10.1111/j.0952-3383.2004.00335.x

Allinder, R. M. (1994). The relationship between efficacy and the instructional practices of special education teachers and consultants. Teacher Education and Special Education, 17(2), 86-95. doi: $10.1177 / 088840649401700203$

Avramidis, E., Bayliss, P., \& Burden, R. (2000). Student teachers' attitudes toward the inclusion of children with special educational needs in the ordinary school. Teaching and Teacher Education, 16(3), 277-293. doi: 10.1016/S0742-051X(99)00062-1

Avramidis, E., \& Norwich, B. (2002). Teachers' attitudes toward integration/inclusion: A review of the literature. European Journal of Special Needs Education, 17(2), 129-147. doi: $10.1080 / 08856250210129056$

Bandura, A. (1997). Self-efficacy: The exercise of control. New York: W. H. Freeman.

Brownell, M. T., \& Pajares, F. (1999). Teacher efficacy and perceived success in mainstreaming students with learning and behavior problems. Teacher Education and Special Education, 22(3), 154-164. doi: 10.1177/088840649902200303

Buell, M. J., Hallam, R., Gamel-Mccormick, M., \& Scheer, S. (1999). A survey of general and special education teachers' perceptions and inservice needs concerning inclusion. International Journal of Disability, Development and Education, 46(2), 143-156. doi: 10.1080/103491299100597

Center, Y., \& Ward, J. (1987). Teachers' attitudes toward the integration of disabled children into regular schools. The Exceptional Child, 34(1), 41-56. doi: 10.1080/0156655870340105

Chao, C. N. G., Sze, W., Chow, E., Forlin, C., \& Ho, F. C. (2017). Improving teachers' self-efficacy in applying teaching and learning strategies and classroom management to students with special education needs in Hong Kong. Teaching and Teacher Education, 66, 360-369. doi: 10.1016/j.tate.2017.05.004

Davis, M. J. (2010). Contrast coding in multiple regression analysis: Strengths, weaknesses, and utility of popular coding structures. Journal of Data Science, 8(1), 61-73.

deBettencourt, L. U. (1999). General educators' attitudes toward students with mild disabilities and their use of instructional strategies: Implications for training. Remedial and Special Education, 20(1), 27-35. doi: 10.1177/074193259902000104 
De Boer, A., Pijl, S. J., \& Minnaert, A. (2011). Regular primary school teachers' attitudes towards inclusive education: A review of the literature. International Journal of Inclusive Education, 15(3), 331-353. doi: 10.1080/13603110903030089

Delacre, M., Lakens, D., \& Leys, C. (2017). Why psychologists should by default use Welch's t-test instead of Student's t-test. International Review of Social Psychology, 30(1), 92-101. doi: 10.5334/irsp.82.

Desombre, C. (2011). Analyse psychosociale de l'intégration des élèves en situation de handicap. [Psychosocial analysis of students with SEN integration]. Pratiques psychologiques, 17(4), 391-403. doi:10.1016/j.prps.2009.04.006

Dussault, M., Villeneuve, P., \& Deaudelin, C. (2001). L'échelle d'autoefficacité des enseignants: Validation canadienne-française du Teacher efficacy scale [The teachers self-efficacy scale: Canadian-French validation of the teacher efficacy scale]. Revue des Sciences de l'Education, 27(1), 181-194. doi: 10.7202/000313ar

Ebersold, S., Plaisance, E., \& Zander, C. (2016). Ecole inclusive pour les élèves en situation de handicap. Accessibilité, réussite scolaire et parcours individuels. [Inclusive school for students with SEN. Accessibility, achievement and individual journey]. In Conseil national d'évaluation du système scolaire-CNESCO (chair), Conférence de comparaisons internationales. Paris.

Elliott, S. (2008). The effect of teachers' attitude toward inclusion on the practice and success levels of children with and without disabilities in physical education. International Journal of Special Education, 23(3), 48-55. Retrieved from https://eric.ed.gov/?id=EJ833682

Ferguson, D. L. (2008). International trends in inclusive education: The continuing challenge to teach each one and everyone. European Journal of Special Needs Education, 23(2), 109-120. doi: $10.1080 / 08856250801946236$

Fernandez, A. P. O., Ramos, M. F. H., Silva, S. S. C., Nina, K. C. F., \& Pontes, F. A. R. (2016). Overview of research on teacher self-efficacy in social cognitive perspective. Annals of Psychology, 32(3), 793-802. doi: 10.6018/analesps.32.3.220171

Florian, L. (1998). An examination of the practical problems associated with the implementation of inclusive education policies. Support for Learning, 13(3), 105-108. doi: 10.1111/14679604.00069

Forlin, C., Loreman, T., \& Sharma, U. (2014). A system-wide professional learning approach about inclusion for teachers in Hong Kong. Asia-Pacific Journal of Teacher Education, 42(3), 247260. doi: 10.1080/1359866X.2014.906564

Gibson, S., \& Dembo, M. H. (1984). Teacher efficacy: A construct validation. Journal of Educational Psychology, 76(4), 569-582. doi: 10.1037/0022-0663.76.4.569

Guskey, T. R., \& Passaro, P. D. (1994). Teacher efficacy: A study of construct dimensions. American Educational Research Journal, 31(3), 627-643. doi: 10.3102/00028312031003627

Hayes, A. F. (2009). Beyond Baron and Kenny: Statistical mediation analysis in the new millennium. Communication monographs, 76(4), 408-420. doi: 10.1080/03637750903310360 
Holzberger, D., Philipp, A., \& Kunter, M. (2013). How teachers' self-efficacy is related to instructional quality: A longitudinal analysis. Journal of Educational Psychology, 105(3), 774-786. doi: $10.1037 / \mathrm{a} 0032198$

Klassen, R. M., \& Chiu, M. M. (2010). Effects on teachers' self-efficacy and job satisfaction: Teacher gender, years of experience, and job stress. Journal of Educational Psychology, 102(3), 741756. doi: $10.1037 / \mathrm{a} 0019237$

Lancaster, J., \& Bain, A. (2007). The design of inclusive education courses and the self-efficacy of preservice teacher education students. International Journal of Disability, Development and Education, 54(2), 245-256. doi: 10.1080/10349120701330610

Leatherman, J. M., \& Niemeyer, J. A. (2005). Teachers' attitudes toward inclusion: Factors influencing classroom practice. Journal of Early Childhood Teacher Education, 26(1), 23-36. doi: 10.1080/10901020590918979

Leyser, Y., Zeiger, T., \& Romi, S. (2011). Changes in self-efficacy of prospective special and general education teachers: Implication for inclusive education. International Journal of Disability, Development and Education, 58(3), 241-255. doi: 10.1080/1034912X.2011.598397

Mahat, M. (2008). The development of a psychometrically-sound instrument to measure teachers' multidimensional attitudes toward inclusive education. International Journal of Special Education, 23(1), 82-92. Retrieved from https://eric.ed.gov/?id=EJ814377

MacFarlane, K., \& Woolfson, L. M. (2013). Teacher attitudes and behavior toward the inclusion of children with social, emotional and behavioral difficulties in mainstream schools: An application of the theory of planned behavior. Teaching and Teacher Education, 29, 46-52. doi: 10.1016/j.tate.2012.08.006

McHatton, P. A., \& Parker, A. (2013). Purposeful preparation: Longitudinally exploring inclusion attitudes of general and special education pre-service teachers. Teacher Education and Special Education, 36(3), 186-203. doi: 10.1177/0888406413491611

Meijer, C. J. (2010). Special needs education in Europe: Inclusive policies and practices. Zeitschrift für Inklusion, 4(2). Retrieved from http://www.inklusion-online.net/index.php/inklusiononline/article/view/136/136.

Minke, K. M., Bear, G. G., Deemer, S. A., \& Griffin, S. M. (1996). Teachers' experiences with inclusive classrooms: Implications for special education reform. The Journal of Special Education, 30(2), 152-186. doi: 10.1177/002246699603000203

Morris, D. B., Usher, E. L., \& Chen, J. A. (2016). Reconceptualizing the sources of teaching selfefficacy: A critical review of emerging literature. Educational Psychology Review, 1-39. doi: 10.1007/s10648-016-9378-y

Plaisance, E. (2012). Integration or inclusion. In Kron, M. (ed.). Growing up Together. Steps to Early Inclusive Education (p. 23-30). Siegen: ZPE. 
Preacher, K. J., \& Hayes, A. F. (2004). SPSS and SAS procedures for estimating indirect effects in simple mediation models. Behavior Research Methods, Instruments, \& Computers, 36(4), 717731. doi: 10.3758/BF03206553

Preacher, K. J., \& Hayes, A. F. (2008). Asymptotic and resampling strategies for assessing and comparing indirect effects in multiple mediator models. Behavior Research Methods, 40(3), 879-891. doi: 10.3758/BRM.40.3.879

Rattaz, C., Ledesert, B., Masson, O., Ouss, L., Ropers, G., \& Baghdadli, A. (2013). La scolarisation des enfants avec Troubles du spectre autistique (TSA) en France: l'expérience d'enseignants en classe ordinaire et spécialisée. [Students' with Autisitc Spectrum Disorders schooling in France: General and Special education teachers' experiences]. La Nouvelle Revue de l'Adaptation et de la Scolarisation, 64 (4), 255-270. doi : 10.3917/nras.064.0255

Ruijs, N. M., \& Peetsma, T. T. (2009). Effects of inclusion on students with and without special educational needs reviewed. Educational Research Review, 4(2), 67-79. doi: 10.1016/j.edurev.2009.02.002

Savolainen, H., Engelbrecht, P., Nel, M., \& Malinen, O. P. (2012). Understanding teachers' attitudes and self-efficacy in inclusive education: implications for pre-service and in-service teacher education. European Journal of Special Needs Education, 27(1), 51-68. doi: $10.1080 / 08856257.2011 .613603$

Schiefele, U., \& Schaffner, E. (2015). Teacher interests, mastery goals, and self-efficacy as predictors of instructional practices and student motivation. Contemporary Educational Psychology, 42, 159-171. doi: 10.1016/j.cedpsych.2015.06.005

Scruggs, T. E., \& Mastropieri, M. A. (1996). Teacher perceptions of mainstreaming/inclusion, 19581995: A research synthesis. Exceptional Children, 63(1), 59-74. doi: $10.1177 / 001440299606300106$

Shippen, M. E., Crites, S. A., Houchins, D. E., Ramsey, M. L., \& Simon, M. (2005). Preservice teachers' perceptions of including students with disabilities. Teacher Education and Special Education, 28(2), 92-99. doi: 10.1177/088840640502800202

Soodak, L. C., Podell, D. M., \& Lehman, L. R. (1998). Teacher, student, and school attributes as predictors of teachers' responses to inclusion. The Journal of Special Education, 31(4), 480497. doi: $10.1177 / 002246699803100405$

Takala, M., Haussttätter, R. S., Ahl, A., \& Head, G. (2012). Inclusion seen by student teachers in special education: Differences among Finnish, Norwegian and Swedish students. European Journal of Teacher Education, 35(3), 305-325. doi: 10.1080/02619768.2011.654333

te Grotenhuis, M., Pelzer, B., Eisinga, R., Nieuwenhuis, R., Schmidt-Catran, A., \& Konig, R. (2017). When size matters: advantages of weighted effect coding in observational studies. International Journal of Public Health, 62(1), 163-167. Doi: 10.1007/s00038-016-0902-0 
Thomazet, S. (2008). L'intégration a des limites, pas l'école inclusive! [Integration has limits, not the inclusive school!]. Revue des Sciences de l'Education, 34(1), 123-139. doi: 10.7202/018993ar

Tournaki, N., \& Samuels, W. E. (2016). Do graduate teacher education programs change teachers' attitudes toward inclusion and efficacy beliefs? Action in Teacher Education, 38(4), 384-398. doi: $10.1080 / 01626620.2016 .1226200$

United Nations Educational, Scientific and Cultural Organisation. (1994). The Salamanca Statement and Framework for Action on Special Needs Education. ED-94/WS/18. Paris: Author.

Retrieved from http://www.ecdgroup.com/download/gn1ssfai.pdf

Urton, K., Wilbert, J., \& Hennemann, T. (2014). Attitudes towards inclusion and self-efficacy of principals and teachers. Learning Disabilities: A Contemporary Journal, 12(2), 151-168. Retrieved from https://eric.ed.gov/?id=EJ1047459

Vislie, L. (2003). From integration to inclusion: Focusing global trends and changes in the western European societies. European Journal of Special Needs Education, 18(1), 17-35. doi: $10.1080 / 0885625082000042294$

Ward, J., Center, Y., \& Bochner, S. (1994). A question of attitudes: integrating children with disabilities into regular classrooms? British Journal of Special Education, 21(1), 34-39. doi: 10.1111/j.1467-8578.1994.tb00081.x

Weisel, A., \& Dror, O. (2006). School climate, sense of efficacy and Israeli teachers' attitudes toward inclusion of students with special needs. Education, Citizenship and Social Justice, 1(2), 157174. doi: $10.1177 / 1746197906064677$

Wertheim, C., \& Leyser, Y. (2002). Efficacy beliefs, background variables, and differentiated instruction of Israeli prospective teachers. The Journal of Educational Research, 96(1), 54-63. doi: $10.1080 / 00220670209598791$

Wilson, C., Woolfson, L. M., Durkin, K., \& Elliott, M. A. (2016). The impact of social cognitive and personality factors on teachers' reported inclusive behaviour. British Journal of Educational Psychology, 86(3), 461-480. doi: 10.1111/bjep.12118

Woolfolk Hoy, A., Hoy, W. K., \& Davis, H. A. (2009). Teachers' self-efficacy beliefs. In K. Wentzel, \& A. Wigfield (Eds.), Handbook of Motivation in School (pp. 627-655). Mahwah, NJ: Lawrence Erlbaum.

Yada, A., \& Savolainen, H. (2017). Japanese in-service teachers' attitudes toward inclusive education and self-efficacy for inclusive practices. Teaching and Teacher Education, 64, 222-229. doi: 10.1016/j.tate.2017.02.005

Zee, M., \& Koomen, H. M. (2016). Teacher self-efficacy and its effects on classroom processes, student academic adjustment, and teacher well-being: A synthesis of 40 years of research. Review of Educational Research, 86(4), 981-1015. doi: 10.3102/0034654315626801 